\title{
From culture to class - legitimate boundary making in German immigration debates on Southern and Eastern Europeans
}

\author{
Christian Ulbricht巴D
}

Correspondence: christian.ulbricht@ uni-bielefeld.de

Faculty of Sociology, Bielefeld University, P.O. Box 1001 31, 33501 Bielefeld, Germany

\begin{abstract}
The article depicts symbolic boundary making in the German discourse on immigration. The analysis addresses the question of how wanted and unwanted immigrants are socially constructed and thereby differentiated in this discourse. The media analysis from 2008 to 2014 of so-called poverty migration from Rumania and Bulgaria and so-called new guest workers from Greece, Italy and Spain suggest that boundary making against these immigrants shifts from ethnicity and religion to an individual class-based approach. In this respect, the article discusses how a strong human rights discourse makes a dominant individualistic class-based definition of (un-) wanted immigration more likely. However, the analysis also shows that this construction of desirability refers to the ethnicity of the immigrants. In this sense, ethnic boundary making is stable in a liberal-universalistic context.
\end{abstract}

Keywords: Liberal paradox, Boundary making, Germany, Wanted immigrants, Guest workers, Poverty immigration, Discourse analysis

\section{Introduction}

In this paper I draw on the argument that the social inclusion and exclusion of immigrants becomes increasingly problematic for those nation states who are under the influence of a strong human rights discourse. In this sense, some authors see evidence for a boundary crisis of the liberal nation state due to liberal norms that limit the state choices of inclusion and exclusion (Adamson, Triadafilopoulos, \& Zolberg, 2011). The foundation of this crisis is well known to be the liberal paradox of immigration (Benhabib, 1999; Freemann, 1986; Hollifield, 1992; Joppke, 2005). The liberal paradox results from the contradictions of various facets of the modern liberal state. According to Hampshire's (2013) analysis, the liberal state is a capitalist, a constitutional, a democratic and a national state. Each facet of the liberal state carries out a different assessment on immigration. While the constitutional and capitalist facets tend towards more openness for immigrants, the democratic and nationhood facets are associated with more restrictive dynamics. Especially, the imperatives between the universalism of human rights established in the constitution of liberal-democratic nation-states and the particularism of nationhood is central to the liberal paradox. In this paper I use the boundary making approach (Wimmer, 2013) to understand the conflictual dynamics of

(c) The Author(s). 2019 Open Access This article is distributed under the terms of the Creative Commons Attribution 4.0 International License (http://creativecommons.org/licenses/by/4.0/), which permits unrestricted use, distribution, and reproduction in any medium, provided you give appropriate credit to the original author(s) and the source, provide a link to the Creative Commons license, and indicate if changes were made. 
the four facets more in detail in order to examine how they interact to produce an evaluation of (un-)wanted immigration.

More specifically then, how are immigrants categorised and evaluated by actors in the context of a liberal nation-state that contains both a universal human rights discourse and particularistic and exclusive national definition of who is (un-)wanted? This symbolic struggle over the legitimate principle of vision and division on the evaluation and categorisation of (un-)wanted immigrants is at the heart of the empirical analysis in this article. Since religion in Western Europe (Zolberg \& Woon, 1999) and especially strong religious and ethnic boundaries in Germany (Alba, 2005; Diez \& Squire, 2008) are seen as the dominant characteristics in the symbolic dimension of the boundary making referring to an ethnic conceptualization of German nationhood (Brubaker, 1992; Koopmans, Stathan, Giugni, \& Passy, 2005), I discuss how class as a generalized category by which I mean education, occupation, and income has come to replace them.

In the following, I will first describe my theoretical approach to study the boundary making. I discuss the extent to which a distinction between the wanted and unwanted immigrants is reflected in a symbolic hierarchy of categories of mobility and migration. Second, I will give a short overview about my methodological approach. The realisation of categories is analysed through two case studies. I will explore how the supposedly wanted "new guest workers" from Spain, Italy and Greece and the unwanted "poverty immigrants" from Rumania and Bulgaria are represented in the discourse on immigration in Germany from 2006 until 2014. In the final part, I will compare and discuss the results of these two intra-European migration cases.

\section{Theoretical approach}

The analysis of the social construction of wanted and unwanted immigrants can be observed in diverse arenas of boundary making. This research follows the idea of an analytic distinction between social and symbolic boundaries (Lamont \& Molnár, 2002). Intense political and legal research has shown that states are trapped in the liberal paradox (Hollifield, 1992) but have also reacted to it (see Orgad, 2015 ch. 4-6 for an overview). These studies are concerned with the institutionalised social boundaries involving primarily citizenship policies (Howard, 2006; Janoski, 2010; Koopmans, Michalowski, \& Waibel, 2012) and studies of integration policies (Banting \& Kymlicka, 2013; Goodman, 2010, 2011, 2015; Joppke, 2007). On a very general level, we can observe in most of the western democracies that citizenship acquisition is becoming increasingly accessible for migrants. But in this overarching liberal framework some scholars refer to restrictive trends which have recently been witnessed and coined by the terms civic integrationism (Joppke, 2007), schmittanian liberalism (Triadafilopoulos, 2011) or communitarian neoliberalism (van Houdt \& Schinkel, 2013; van Houdt, Suvarierol, \& Schinkel, 2011). Thus, these terms point to the fact that "today it's not a Question of 'Who has Access?' but rather under what conditions does someone with eligibility obtain citizenship?" (Goodman, 2010, p. 757).

Some scholars interpret these developments as a shift in boundaries: From an ethnic to a neoliberal form of inclusion and exclusion in which the approach to select immigrants on an individual skill level is favoured over a group-based approach (Schmidtke, 2012; Soysal, 2012). What has been less analysed is how the liberal paradox is negotiated within the symbolic dimension of boundary making. The theoretical argument 
states that only when symbolic boundaries are widely agreed upon, they can become social boundaries like citizenship and integration policies (Lamont \& Molnár, 2002). This means empirically that although recent studies have shown which categories are active in the symbolic boundary making process across various European countries (for an overview see Bail, 2008), we need to study further the interaction and symbolic struggle over the legitimate definition of the categories involved (Bonikowski, 2016). By identifying actors and coalitions constructing and advancing these legitimate categories (Cerna, 2009), we can understand why certain symbolic boundaries are drawn in the first place. Thus, I focus on the elementary strategies of actors drawing boundaries against immigrants (Wimmer, 2008). Legitimation refers here in a Bourdieu's notion to the ability of actors to impose a criterion of evaluation of wanted and unwanted immigrants. This requires an intersubjective agreement or disagreement about the standards against which the immigrants are evaluated (Lamont, 2012).

In order to get an conceptual understanding of who is (un-)wanted, I shall review the literature that sheds light on how the public symbolically categorise the "wanted and welcome" and "the wanted and not welcome" immigrants, to quote Zolberg (1987, p. 37) - 'Wanted' in an economic sense and 'welcome' in a cultural sense. The wanted and welcome (Triadafilopoulos \& Smith, 2013) are the (highly) skilled persons as in times of economic crisis they represent a key to innovation and creativity in a knowledge-based economic surrounding. The spatial movement of the highly skilled mobiles is considered to be economically efficient and desirable (Faist, 2013). In the case of the highly skilled migrants, the absence of a debate on social problems concerning the integration of these migrants or any other negative cultural coding is striking. Thus, their mobility as a privileged form of migration is constructed through a positive economic and cultural evaluation.

Figure 1 suggests that desirable immigrants are more likely to be perceived as autonomous mobile human capital holders. Undesirable immigrants, on the other hand,

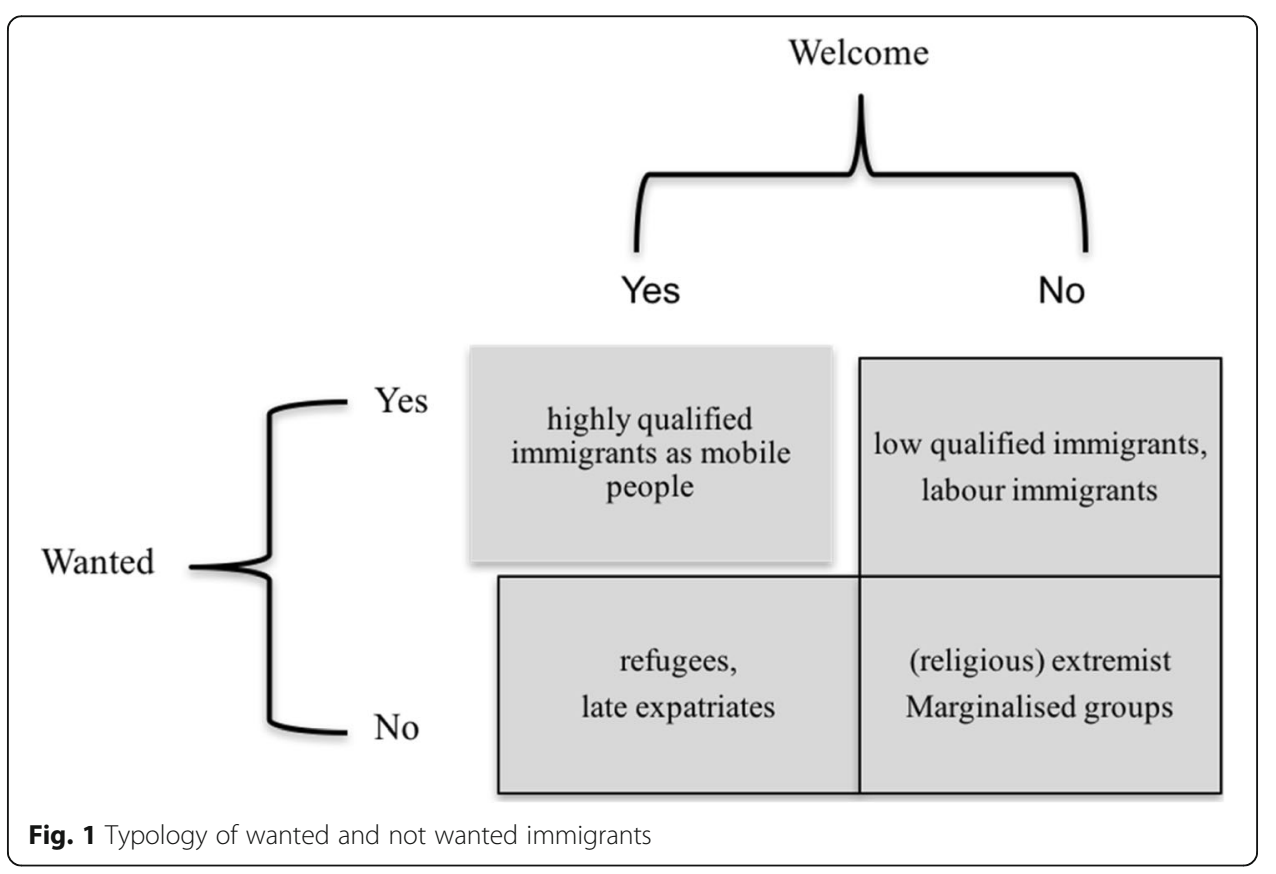


are perceived as "social problems". Thus, even the wanted and welcome immigrants are never perceived as citizens who are there to stay. However, their mobility is still perceived as a privileged form of migration.

Compared to the wanted and welcome mobile human capital holders, guest workers are usually "wanted but not welcome" (Zolberg, 1987). On the one hand, the immigrants are wanted in a general way as an external labour supply that reduces the levels of wages in the receiving labour market so that the national labour market is more competitive (Kindleberger, 1967). On the other hand, the guest workers are "not welcome" in a way that alien labour represents an undesirable "otherness". The debates on otherness are, for example, constructed around the concerns of the incompatibility of Islam with democracy and are particularly focused on the subjects of gender equality, forced marriages, honour killings as well as the wearing of the hijab, niqab and burqa (Yurdakul \& Korteweg, 2013). These immigrants are then seen as a threat to the national community and are culturally devalued (Faist, 2014). Refugees, in contrast, are not wanted economically, but self-commitment of the nation state to respect human rights would, in principle, guarantee a policy of openness towards refugees. Because of this, they can be conceptualised as 'welcome' (Hampshire, 2013). Resettlers can be defined as belonging to the community by the mainstream society through their ethnic descent and so they are also welcome. Nevertheless, it is important here to understand more empirically the extent to which diverse categories e.g. class, ethnicity and religion intersect, thus guaranteeing openness towards economically unwanted migration. Migrants who are neither utilisable in capitalist logic nor compatible with culture are labelled as unwanted and unwelcome.

\section{Methodology}

How are migration-related classifications socially constructed and how do they manifest in symbolic boundaries? In order to answer these questions, I analyse news articles that discuss explicitly on the one hand the wanted and welcome and on the other hand the not wanted and not welcome immigration to Germany. I used news articles because public debates construct an arena for the "visibility, agenda-setting and framing" (Bleich, Bloemraad, \& de Graauw, 2015) of politically relevant themes and actors that are important for framing different types of immigrants with different threats (Hellwig \& Sinno, 2016). Here, Germany is a particularly good case for understanding symbolic boundary making in liberal nation states as we know from a previous study that the liberal paradox has become an important feature of German public debate on immigration (Schmidtke, 2008). Although the analysis focuses on Germany, the liberal paradox is present in other European liberal nation-states as well. Thus, the understanding how the liberal paradox is negotiated in the German media can contribute to the discussion which facets in other European nation-states play a key role in explaining openness and closeness towards immigration (Hampshire, 2013). Similar to Germany, Northern European countries faced a South-North migration from Spain, Greece, Italy and Portugal since the 2008 financial crisis (Bartolini, Gropas, \& Triandafyllidou, 2016; O'Reilly et al., 2015).

Examining the social construction on (un-)wanted immigrants in the media by analysing their narrative structure (Keller, 2012) makes it possible to place the process of categorisation and legitimation at the centre of the analysis in order to find out more about the conflictual assessment of immigrants and how immigrants are ascribed into 
certain categories. In the following, I describe the process of analysis chronologically, starting with the construction of the two case studies.

The case design of the "new guest workers" and the "poverty immigration"

The case construction was guided, on the one hand, by the empirical findings of Eder, Rauer, and Schmidtke (2004) which identified a juxtaposition of discourses on the threatened cultural national identity and the demographically and economically required immigration. The goal was to understand in which terms, events, narratives, etc., the different and parallel discourses about the endangered national identity and the skilled labour force are represented. In other words, which categories of practice are used in the media to describe the wanted and not wanted immigrants. I identified two leading articles in Der Spiegel ("The German Dream" (Becker et al., 2013) and "Pallet without a Pillow" (Schmid, \& Ulrich, 2013)), which explicitly contained a positive and negative normative evaluation of immigrants. These two articles served as the starting point for my sampling. The (highly) qualified specialists were called "new guest workers", which migrated from Italy, Spain and Greece to Germany. The comparison between the "generations" of guest workers instigated and informed a search for further evidence concerning "new guest workers" in the media. The following questions were addressed at this point: How are the guest workers retrospectively assessed? What does integration mean for guest workers? What are the economic and cultural expectations directed at the "new guest workers"? The article "Pallet without a Pillow", which was embedded in the article on the "new guest workers", mentions "poverty immigration" to Germany. The term "poverty immigration" is used by the media specifically to describe the migrants from Romania and Bulgaria to Germany, who are thus depicted as people who hope to escape extreme poverty. In contrast to the "new guest workers", the "poverty immigrants" are described to be low qualified and not wanted. At first glance, "poverty immigration" seemed to be a new category for describing immigration to Germany. The question which informed the further search for articles was: What is meant by the category "poverty immigration"? Does this category also include or exclude an ethnicization of migratory flows from the east of Europe, usually represented in the media through terms such as gypsies or Sinti and Roma? Thus, the case of the not wanted "poverty immigrants" could be used to explain the differences and the similarities in the boundary making towards the wanted qualified "new guest workers".

I argue that these two case studies are productive for the analysis of symbolic boundary making in the German immigration discourse. First, they are ideal cases for a comparison: How is Eastern European migration symbolically being compared with Southern European migration under the paradigm of European free movement? Secondly, the two case studies reflect the three key factors of the German immigration debate which are characterized according to Cornelius, Martin, and Hollifield (1994) by (a) a prognosis of a declining supply of labor, (b) the need to politically and socially integrate the long-settled guest workers, and (c) the fear of a massive and uncontrolled immigration from Eastern Europe. Therefore, a methodically controlled case description of "poverty immigration" and the "new guest workers" was developed. The investigation period was set from 01.01.2008 to 31.07.2014 as Germany registered at this time an increase in immigration during the European economic recession and fiscal crisis. 


\section{Data selection and data interpretation}

The data collection contained eight quality mainstream media corporations and their respective online outlets. The selected sources had to be used as reference media by other news formats in the national press and on television, such as the Frankfurter Allgemeine Zeitung (FAZ), tagesschau.de and Der Spiegel. They had to have a left or right-wing political tendency, such as Taz and Die Welt. The websites used as sources had to be the most popular in the online news sector, such as Bild, Stern, Focus. The rationale for this selection strategy was the assumption that these sources were read directly and indirectly by a number of different groups in society and therefore had the potential to frame a great variety of discursive statements.

The articles were selected for the entire sample in two steps. First, the total corpus was recorded as digital archives, each tagged with a corresponding search word ("guest workers" and "poverty immigration"). Instead of the "new guest workers" as a search word, the term "guest workers" was preferred for the sampling strategy in order to cover a huge variety of immigration themes.

In total, the guest worker corpus contains 2758 articles and the poverty immigration corpus 688 articles and up to this point the corpus which contained all kinds of articles (except reader's letter) haven't been examined. The articles are stored in a chronological output, capturing the peaks and slacks of the debate (see the Additional file 1 for the program code). The total corpus was first analysed with corpus linguistic methods (wordlists, keyness, concordance) for each year and for each newspaper in comparison to the total corpus. Building on these results, my empirical approach to study strategies of boundary making is largely inductive and guided by the methodology of the Grounded Theory (Strauss \& Corbin, 1990). Essential for Grounded theory is the simultaneous process of data collection and interpretation. The following reconstruction of the narrative structure of the "poverty immigration" is exemplifying this approach (for an extended discussion of the methodology of both cases see Ulbricht, 2017).

The Fig. 2 shows that the debate on poverty immigration starts in 2013 and continuing strongly in 2014. During the end of December 2013 and the beginning of 2014 the newspapers published the most articles about the poverty immigrations due to a highly controversial political statement of the Christian Democratic Union (CSU). In the CSU paper, the burden on municipalities and cities proved to be a key reason for describing "poverty immigration" as a problematic phenomenon at all. After the identification of the "Deutsche Städtetag" (German Association of Cities) as an important actor in the

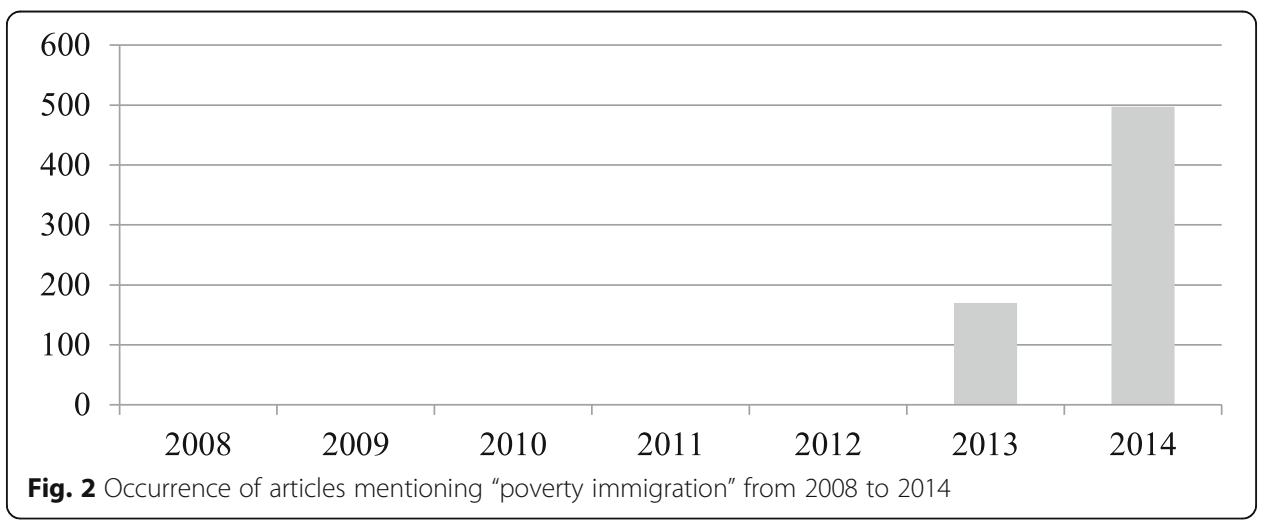


debate, documents were searched that provide clues as to when the "Deutscher Städtetag" becomes relevant for the first time in the debate. Their political statement on "poverty immigration" was published on 22.01.2013 and with the knowledge that the discourse was only constituted in 2013, it can be reasonably assumed that this is the beginning of the debate. The statement was integrated into the sample and openly coded sentence by sentence. It also contains its own narrative on "poverty immigration" making a narration on causes, consequences, responsibilities, claims, and actors involved. In line with the Grounded Theory, I used these causes etc. as concepts which are developed more in detail with the method of theoretical sampling and constant comparison. In other words, which actors use similar arguments in the representation of the causes? Which actors omit the causes and only talk about the consequences for the German Cities? I stopped the simultaneous selection of articles and coding until no further variation in the sense making of a concept was found in the data. Thus, I coded 218 articles in order to trace the causal connections in a discourse, especially how positions and strategies of ethnic boundary making are criticized and how these actors justify their position relying on socially acceptable knowledge.

In the following, the presentation of results is not concerned with a single newspaper text but with the presentation of typical repetitions of discursive statements on the "new guest workers" and on "poverty immigration". I use quotes that exemplify the knowledge that is used to categorize and evaluate the (un-)wanted immigrants.

\section{Results: the new guest workers as the wanted immigrants}

“The new guest workers - Europe's young elite for Germany's economy” (Becker et al., 2013)

In the following, the case of the "new guest workers" is introduced by outlining the historical development of the social construction of guest workers in the media in order to be able to trace (dis-)continuities in the guest worker narrative. This is necessary because actors in the discourse aim to reconstruct the past in a way that fits the needs of the present.

At the time of the first German-Italian recruitment agreement in 1955, the concept of "guest workers" did not characterise the labour migrants. In the mid-fifties, the expression "guest worker" was not yet used (Hubrich, 2009). Rather, terms such as "migrant workers" or, in particular, "foreign workers" (Fremdarbeiter) were deployed. The latter was a term coined by the Nazis for the designation of forced labourers. Because of this negative connotation with the Nazi era, the "friendlier" term "guest worker" was supposed to replace it in the 1960s (Jung, Wengeler, \& Böke, 2000). In addition, in the 1950s the view was not expressed in the media that the guest workers could possibly remain in Germany (Ellermann, 2015). In the 1960s, the attitude towards the guest workers in German media was initially not hostile but rather paternalistic. Up to the first oil crisis (1973), politics and the media tried to convince the population of the benefits of the recruitment (Schönwälder, 2004).

The following description of the story line on the new guest workers shows that the narrative of the former guest workers is used to categorise and evaluate the new migrants from Spain, Italy, Greece and notably not Turkey who went to Germany during the economic recession. The debate is set from above and conducted initially by 
governmental means, advertising the economic benefits of new guest workers. This is best symbolized by the media campaign "I want you for Gastarbeiter" (Elitz, 2010) issued by former Federal Minister of Economy Rainer Brüderle (FDP). The central story line of the discourse on new guest workers is homogeneous and unchallenged in its problem definition. The assumption is that the smooth running of the German economy depends on controlled immigration. The issues of economy and immigration are linked causally through the scarcity of labour supply, which is supposedly caused by demographic change and thus by a lack of skilled labour. The negative correlation between population and professionals is considered to be self-evident and the truthfulness of this relationship is never questioned. As a consequence of this assumption, the argument states that in order not to jeopardise the future growth of the national economy, Germany needs controlled immigration, which distinguishes between desirable and undesirable immigrants in economic terms: "And in the global competition between countries, it is no longer a question of shift workers but of the highly and highest qualified. But they are rare" (Dommer, 2010).

The following typical statements show that the "new guest workers" are defined by their specific relationship with the first wave of labour migration to West Germany: "In contrast to the "guest workers' wave" a few decades ago, companies are now very interested in specialists" (Dribbusch, 2011) or "We are the "new guest workers", now we carry a laptop and diploma with us and no carton with sausages and sardines like the immigrants of the 60s" (Schoepp, 2011). Clear parallels are drawn to the description of guest workers in the 1950s and 1960s. It seems as if the discourse is only able to categorise and legitimise the phenomenon of "new guest workers" as qualified specialists through this relation. In the following short description of the storyline, I would like to highlight the relational aspect to the former guest workers in more detail. The new guest workers were linked to and contrasted with the old guest workers when the discourse focussed on the highly controversial national populist, Thilo Sarrazin, (former member of the Social Democratic Party (SPD) and his claims about the accomplishments of the old guest workers in Germany. Observing this debate, it is clear that statements who identified group-specific characteristics of immigrants, such as religion or ethnicity, to be at the root of "failed integration" came under heavy criticism confirming the symbolic power of the anti-discrimination discourse. Heinz Buschkowsky, the former mayor of the district "Neukölln" in Berlin, who heavily problematised the "failed integration" of immigrants in the media criticised Sarrazin:

"And he does not understand why Sarrazin would have had to ethnize the problems. It is a great pity that a factual debate on Sarrazin's many true considerations is now no longer possible because, with some formulations, he has made his entire concern and analysis unquotable." (Sarrazin, 2009)

In order to draw boundaries between the wanted and unwanted, actors referred to the category of class of the immigrants. This is typical that spokespersons with a high symbolic power in diverse positions in the discursive arena such as the Federal Government, representatives of employers and employees and migrant organisations strongly oppose and criticise an ethnicisation of immigration. This is clearly a strategy of ethnic boundary blurring. The position of rejecting "sweeping judgments" and instead 
focusing on the individual efforts of the immigrants in the education and training market (controlled by integration contracts) came to dominate the debate. Thus, within the discourse, successful integration means a structural and cognitive integration - which in turn means that learning the German language leads to labour market integration. Learning the German language is seen as a precondition for entering the labour market. This is symbolised by former guest workers who display upward social mobility through education and entrepreneurship. In other words, upward social mobility is an integration requirement. Any argument which uses the group-specific characteristics of the immigrants is criticised by human rights activists, various political parties across political front lines, migrant organisations as well as representatives of corporations and unions who say these arguments are racist. What these advocates say about failed integration is directly linked to the class position of the first guest workers; that their education and vocational training made it difficult for them to leave behind their social background, which is an integration requirement. One typical statement in this context reads as follows: "It's unfair to pin down the problems on ethnic groups. For example, for many years we have recruited the less educated classes from Turkey as guest workers" (Laschet, 2009). This is a strategy to de-emphasize ethnic boundaries.

In the debates, the racism critique and the defence of human rights lead to the fact that the actors concerned explicitly take up the accusation and have to reject it: "I am not a racist" (Sarrazin, 2010a). In order to still be able to problematise and discriminate against immigrants, one strategy is the hierarchisation of immigrants according to their education and qualifications. The rejection of Muslim immigrants is then subordinated if they have the appropriate qualification level: "Those who have the qualification requirements discussed in Germany under the keyword "Green Card" can, of course, also come from a Muslim country" (Sarrazin, 2010b).

Thus, the current shared perception of various actors involved in the migration debate in the German media tend to agree that there is a close link between economic productivity and integration into society. Being a good migrant is located in the value of economically productive individuals, which is represented in the discourse by the label "new guest workers". It is assumed, that the new migrants already possess or are willing to learn these desired properties mentioned above, in comparison to those guest workers who came in the 50s and 60s.

In principle, the term "new guest workers" is not a contested term. First of all, the highly qualified guest workers are not considered to be permanent migrants: "The generation of young Italians stands for mobility, not necessarily for permanent migration" (Link, 2012). The main knowledge to categorise and evaluate the "new guest workers" is not derived from the integration debate, but through the economic competitiveness of human capital. What counts are the capabilities of the autonomous citizen who has sufficient academic and vocational qualifications or who has individual motivation and competence of its appropriation so that he or she is not dependent on welfare spending and has a self-reliant life. And according to theses capacities, it is expected that if these migrants stay permanently then they can more successfully be integrated into society on a cultural level than the first guest workers. So the expectation is, so to speak, that the "new guest workers" are not following their ethnic community but their own career in Germany. Through this expectation the contradictory nature of the term "new guest workers" is revealed. The wanted migrant workers are still addressed as guests and not 
as immigrants, but if permanent migration is likely, the integration scenario is more promising than with the first guest workers.

\section{Results: poverty immigration as the not wanted immigrants}

"Special social problems arise when unskilled, unqualified, uneducated workers from Romania and Bulgaria come to Germany." (FAZ, 2014)

The second case illustrates the shifting boundaries in the discourse about "poverty immigration" in Germany. The discourse about "poverty immigration" does not undergo a constant debate but is updated on important events.

The debate on the "poverty immigration" was initiated at the beginning of 2013 by a political position paper of the German City Council. On 22 January 2013, the German City Council asked the Federal Government to recognise the problem of "poverty immigration" and, accordingly, to support cities and municipalities financially in terms of integration. According to the German City Council, the consequences are obvious: On the one hand, the City Council Paper argued that traffickers exploit the "poor immigrants" from Romania and Bulgaria in their 'miserable' situation and therefore are in need of protection. This can lead to the situation that poor immigrants are gaining illegal income, working for dumping wages or pursuing prostitution and begging, thus undermining the social order in different social contexts. On the other hand, the City Council argues that "poverty immigration" in cities and municipalities leads to considerable costs in the areas of the education, social and health care system as well as in the employment and housing market. The City Council warns that right wing, xenophobic forces are exploiting the situation in their favour and this ultimately complicates the integration of the poor immigrants.

The Federal Government takes up this position in February. The Federal Minister of the Interior, Hans-Peter Friedrich (CSU), announces that he will halt "poverty immigration" from Romania and Bulgaria by vetoing the Schengen accession of these countries. In his statements, he reduces the debate about "poverty immigration" to the restriction of migration from Romania and Bulgaria: "Whoever comes to collect social benefits must be effectively deterred, said Friedrich" ("Veto gegen Schengen-Beitritt", 2013). Friedrich thus relied on the knowledge of social burden in order to deploy a strategy of narrowing boundaries to argue against the European freedom of movement for Romanian and Bulgarian citizens. Here, the position of the German City Council is not taken up that "poverty immigration" is not primarily the cause of the social problems but in fact intensifies the social problems that already exist in the city.

He continues to carry forward the position of social burden, which was only partially mentioned by the German City Council and excludes their statements on exploitation and their concern about the danger of right wing instrumentalisation. His statements take centre stage in the discourse on poverty migration because from this time onwards the issue of poor peoples' international mobility within Europe becomes part of a discussion about the pros and cons of free European movement.: "Free movement also has a flip side of the coin" (FOCUS, 2013).

The burden for Germany is understood, above all, as a burden for the German welfare state. According to the discourse reproduced in the media, the influx of "poor 
immigrants" may lead to rising rents for the long-term unemployed, an increase in state support to guarantee education, health care and other essential social support for poor migrant families who cannot assume these costs independently. The media portrays that the poverty immigrants increasingly compete with homeless Germans for shelter. The social comparison of the immigrants from Rumania and Bulgaria to the German unemployed and the German homeless designate the social position they have in the social space.

The positive arguments made about "poverty immigration" are mainly constructed by refuting the negative aspects mentioned above. From this pro-immigration perspective, "poverty immigration" is not constructed as a burden for the social welfare state. Instead, there is the impression that Germany profits economically from these immigrants. This claim is demonstrated using elaborate statistics stating that poor migrants are not necessarily poorly qualified: " 25 per cent have a university degree, 40 per cent vocational training, 35 per cent have no qualifications, according to a study by the Institut für Arbeitsmarkt- und Berufsforschung (Institute for Employment Research)" ("Stürmen Rumänen und Bulgaren”, 2013). This is in direct opposition to the former argument of poverty immigrants being a burden, and with qualified immigration the deficit of skilled workers and the challenges of demographic change can be counteracted. In the dispute over the two sides of the freedom of movement coin, the poor immigrants are defined either as an economic burden or as an economic asset. The different positions are seen as a corrective critique within an economic perspective.

In the first phase of the debate, the restriction of "poverty immigration" to Germany is strongly associated with a restriction of Roma immigration: "For weeks now, the Federal Minister of the Interior, Hans-Peter Friedrich, has urged the need to prevent the immigration of poverty from Roma to Germany" (Dribbusch, 2013). He argues that the incentives for Sinti and Roma to come to Germany have to be reduced by significantly improving the living conditions in the countries of origin. When speaking about the Roma, the discourse does not coherently represent the Roma. Among other things, the Roma's family situation and their integration into the city is seen as very problematic for many actors who seek to justify the restriction of "poverty immigration": "Roma and Sinti are to be considered different because they live in large family associations. Integration measures are thus becoming more and more difficult" (FOCUS, 2013). In addition, the Roma are described as poorly educated which is said to cause immediate problems on the labour market: "The concern is huge that precisely these people seek refuge in Germany in order to benefit from social welfare" ("Droht Deutschland eine Roma-Welle?", 2013). At the same time, the issue of "poverty immigration" and Roma is also considered a "delicate issue" (Seibel, 2013) because of the racist suspicion that is inevitably raised. This anti-discrimination position refutes a general suspicion against a minority and points out the problematic linkage between attributing negative stereotypes to a whole minority. Advocates of the poverty immigration argue that the main problem lies in the catastrophic living conditions of Roma in their homelands. Thus, in the debate we find controversial statements leading to an intensified discrimination, a fact that is also critically reflected. These positions run parallel in the discourse and do not relate to each other. In other words, critical left-wing newspapers report on the discrimination of Roma whereas the mainstream tabloid press like the "Bild" newspaper keeps quiet about it. 
These observations change dramatically in the New Year's debate of 2013/14. The CSU paper "Do not encourage poverty in the municipalities" is the starting point of the New Year's debate. The CSU rejects the "immigration of poverty" into "our social security systems" and wants to take action against the 'abuse' of European free movement under the motto "those who cheat, go." The CSU calls for a general suspension of social benefits for the first 3 months of stay in Germany and a re-entry ban on social fraud. The CSU justify this position by using the argument about financial burden on the German welfare state. The CSU fears that German citizens will turn against European freedom of movement as a result of massive "poverty immigration". A boundary spanning discursive coalition of political, economic, and social actors builds up against the CSU. The criticism of the CSU is clear and uniform. The freedom of movement is defended, on the one hand, by the argument of economic necessity and, on the other hand, by the moral argument that the position of the CSU is openly racist and xenophobic. The joint declaration of DGB (German Trade Union Confederation) and BDA (Federation of German Employers) on the freedom of movement in Europe is widely cited in the media as an argument against the CSU and states: "The right to settle in another country and to work is one of the basic values of the European Union. It makes an important contribution for securing skilled workers, to the competitiveness of the German and European economy and to cultural diversity [...]" (Deutscher Gewerkschafts Bund, 2014). Under the umbrella of a social welfare association, more than 150 migrant organisations protest against the CSU: "There is no continuing abuse of the free movement of persons in Europe by "poverty immigrants"." (Spiegel Online, 2014). They appeal to the CSU: "Please prevent a campaign taking place at the expense of the migrants that plays on the fears of the citizens" (Spiegel Online, 2014). In the end, when the term "social benefit tourism" is chosen as the ugliest word of the year (14.01.2014), the debate is normatively clear: "poverty immigration" does not exist and the word is highly problematic and can no longer be used. The generalisation of all immigrants from Romania and Bulgaria as synonymous with "poverty immigration" is heavily problematised by political opponents relying on employment statistics of the Institute for Employment Research. Then, some remarkable shifts in the positions of the discourse are observed that indicate the power of anti-discrimination positions together with a positive economic evaluation of the so called "poverty immigration" in the discourse. The formerly strongly dramatising media, such as Bild, Focus and Die Welt clearly stand up for the immigration of people from Romania and Bulgaria or criticise the fear of "poverty immigration" which they had previously fuelled by describing the immigration as a wave which was flooding German cities. Actors generally dissociate themselves from the use of the term in the discourse: "The ghost of mass immigration" (Schütz, 2014), which the CSU propagates, is unmasked as a myth, showing that Germany is economically profiting from this "poverty immigration". At the end of the debate in May 2014, the term "poverty immigration" vanishes from the discourse as fast as it popped up at the beginning of 2013. This shows what Bourdieu called the "symbolic efficacy", which depends on the degree to which the categories proposed are founded in reality (Bourdieu, 1989, p. 23). If the phenomenon is declared by a powerful coalition of scientists and other public administrations to not exist in reality, the symbolic struggle to define the term "poverty immigration" brought up by the Federal Minister of the Interior will lead nowhere. 
At the end of the New Year's debate, when the question was clarified whether "poverty immigration" is an enrichment or burden, the term "poverty immigration" was considered defamatory. For example, Die Welt comments on January 14, 2016:

"POVERTY IMMIGRATION: The CSU uses the term poverty immigrants to describe low-skilled migrants who want to take, in the party's opinion, advantage of social benefits in Germany, but lack opportunities in the labour market. Experts, however, believe it is unjustified to speak categorically of poverty immigration from Bulgaria and Romania. Although immigrants from these countries are on average less well-qualified, the unemployment rate for both nationalities in mid-2013 was below the average of the population as a whole and well below that of other migrant groups."

This editorial position by Die Welt on the discourse comes at the end of the debate. It gives the impression that this definition of the phenomenon was clear right from the beginning but this definition lacks the cultural interpretive schema of the Roma. At the beginning "poverty immigration" was very much about Roma immigration as the restriction of immigration is also explicitly linked in the media to the Roma: "Reduce incentives for the Sinti and Roma" (Bauer, 2013). Concerning the question of how this change in sense-making came about, I argue that the knowledge about the positive economic impact of the poverty immigration has become the dominant principle to evaluate immigrants in the discourse underscored by the anti-discrimination against the Roma immigration. The use of the narrative of the two sides of the coin "of European free movement" is an economic interpretation of migration in Europe. In this positive information campaign in the media on the immigration from Bulgaria and Romania it can be shown how the economic interpretation of migration at the same time displaces an ethnicisation of the migration. On the basis of statistics and expert opinion in the debates, it is elaborately demonstrated that the "poor immigrants" are generally not badly educated. On the contrary, $25 \%$ have a university degree. In this positive reversal of the argumentation, however, the exclusion of Roma is no longer subject to the debate. In other words, the economic positively accessed migrants are then not subject to ethnicisation processes.

In summary, the analysis of the debate demonstrates how changeable a discourse on migration can be. Initially described as a dangerous mass phenomenon threatening Germany's social security system, the problem is declared to be non-existent in a remarkable consensus in the course of determining the phenomenon of "poverty immigration".

\section{Discussion and conclusion}

How are wanted and unwanted immigrants socially constructed in German immigration discourse? The examples of "new guest worker" and "poverty immigration" have shown which categories are used in this boundary making and which of them are recognised in the public debate as legitimate. The question looms large of whether political conflicts are constructed by means of various categories, such as ethnicity, religion or gender. The common theory is that in modern societies conflicts tend to develop from class politics to cultural politics (from class to culture) (Hechter, 2004).

In both case studies the construction of wanted and unwanted immigrants in Germany was carried out with the characteristic of the class position, which differentiates immigrants along the meritocratic triad of social status definitions (education, 
occupation, income). Those, who are being productive and active on the labour market are wanted. This corresponds to the neoliberal currents that underlie the transformation of the "European" social project (Soysal, 2012), which privileges the individual as the main force for social cohesion and solidarity.

This meritocratic idea was clearly evident during the 2008-2014 investigation period, both in the case of the "new guest workers" and "poverty migration". Here, class as a category of practice produces a consensus on the question of who is a wanted and who is an unwanted immigrant. First, class is a recognised as a legitimate boundary in the way that it is the least critical position. Second, class is used by political actors who claim to be advocates of the symbolically excluded, as well as from actors who symbolically exclude immigrants and have to rely on legitimate justifications of their positions. Thus, class is recognised as transcendent by competing actors.

Moreover, this analysis requires us to put more (theoretical) emphasis on the distinct categories that are used in the process of boundary making, eo ipso group making. We can ask whether class as the dominant practice of categorization is different for the possibility of boundary crossing than for example religion. Here, the boundary is basically open and exceedable for immigrants through an individual effort in the realm of education, income and jobs. Learning languages and skills usually have additive effects. Unlike religion, that employs socially exclusive categories to create differences. You can't be a Muslim and a Christian at the same time. It is a common sociological idea that the act of boundary making creates the groups (Barth, 1969; Wimmer, 2013) but this analysis shows that in the act of demarcation the content of the boundary making (class, ethnicity, religion) is crucial to understand the relations between groups.

In this study I was especially concerned to specify the reasons for the "marketisation" of migration (Favell \& Hansen, 2002). I argue that this class-based construction of (un-)wanted immigrants is functional in the discourse on migration. It is seen as a legitimate strategy to exclude people who lack economic performance without engaging in race, class, nationality or a discussion on gender because everybody is judged on an equal basis, i.e. on human capital. Thus, the study demonstrates how the "marketisation" of migration is reinforced by a discourse on human rights that decries discrimination that is based on ascriptive categories, thus opening up discursive possibilities for economic boundary making. The blurring of ethnic and religious boundaries is enforced by the human rights discourse that stigmatises group-level exclusion, but enables individual-level exclusion based on human capital. This does not mean that the importance of other categories, such as ethnicity or religion, becomes irrelevant in the categorisation of wanted and unwanted immigrants in the immigration discourse, but in the context of the public debate these categories are highly fragile and require justification. The characteristics of the competences, qualifications and economic activities of the immigrants are more acceptable in the discourse. They have a dominant place in the discourse, both in the construction of desirability and in the case of undesirability, since they are not subjected to a criticism. These characteristics are instead self-evident and widely recognised.

The narrative of the guest worker is once again active to describe the wanted immigrants in Germany. Thus, the analysis demonstrated that Gary Freeman was correct in 1995 when he observed that "the politics of immigration in these states is haunted by the mistakes, failures, and unforeseen consequences of the guest worker era (...) This 
message is so deeply seared into the public's consciousness (...)" (Freeman, 1995, p. 890). But at this point, it is appropriate to look more closely at the relationship between the categories of ethnicity and class. We might think that an ethnicised boundary making is illegitimate but there is a complex interrelationship between class and the ethnicity category which needs to be considered more in detail. The term guest worker is a highly ethnicised category in itself. As we know from the studies of Schönwälder (2004) "why Germany's guest workers were largely Europeans" the former officials of the government tried to keep out Africans and Asians in order to have tighter immigration controls. This was due to the fear in the government's opinion that non-European immigrants were more likely to remain in Germany. In essence, German officials of the government have assumed that European migrant workers can be better managed. Similarly, the drafting of the German Migration Law from 2000 was influenced by past integration concerns with the resident Turkish population in Germany (Paul, 2013). One might think now that there is certainly a wide gap between the statements made in the public debate and the action of policy makers behind closed doors. Since 2011 the fundamental German Labour Migration policy goal is to secure skilled labour supply and to fight the demographic crisis by a heightened and more coordinated EU Mobility (Paul, 2016). Most importantly, the guest worker discourse in the media serves exactly this purpose as it advertises the recruitment of intra-European labour. More specifically, when the former Minister of economic affairs introduced his campaign "I want you for Gastarbeiter" in the media, a homogenous interpretation of the immigrants by diverse actors as qualified new guest workers was evolving and establishing. Thus, editorials like "The German Dream" (Becker et al., 2013) legitimizes the migration from southern Europe by describing them in comparison to the old guest workers as better qualified and their prospects for a better social-cultural integration scenario are also more promising. At the same time the discourse leaves out representations of Turkish immigrants. The new guest workers are not Turkish guest worker.

Hence, the boundary making in the symbolic and policy realm are strikingly similar: A labour recruitment hierarchy is based on ethnicity in order to manage migration. In this sense, there is a path dependency of the construction of desired immigrants, which basically rests on ethnic categories but which is presented in the media discourse in a liberal fashion. Despite the predominance of performance characteristics in the construction of desirable immigrants, ethnicity plays a central role in the form of national affiliation. This means that the individualistic merit-based construction of desirability pre-excludes the culturally unwanted immigrants. This should stimulate interest in further research, as it can be argued that ethnic boundaries remain stable where they seem to change in the liberal context.

At the same time, the limitation of the cases of the "new guest workers" and the "poor immigrants" becomes obvious. The examination of the presented thesis would succeed by answering the question of how (highly) qualified non-white immigrants or non-white Europeans are represented in the immigration discourse. In the period 2008-2014, however, this category has not been reported in both cases and therefore no comparative statements can be made. However, I consider this category to be central in order to study the intersection between the attributions of achievement to certain ethnic groups. 
In summary, the findings point to fact that it is not only important to show which categories are involved in the symbolic boundary making but to understand more the relationship between them, when analysing the valuation of immigrants. From the results I obtained, it is clear that the capitalist and universalist facets are the main drivers of the categorization and evaluation of immigrants. The Government, all political parties in the German Bundestag except the CSU, unions, together with employers' associations and representatives of migrant organizations refer to these facets when differentiating between wanted and unwanted immigrants. Likewise, we find a hierarchy of categories in the discourse. Qualification is more crucial than the cultural background. The (highly) qualified people are not considered to be immigrants but mobile people. We can ask if this distinction between mobility and migration is increasing in an era of right-wing populism in order to secure skilled labour.

Moreover, a relationship between ethnicity and class can be assumed. The lower the social status of immigrants and thus the higher the probability of social dependency on the welfare state, the more likely it is that immigrants are symbolically ethnicised. In the guest worker discourse, it has been shown that immigrants who appear unfit for the labour market have been depreciated in their value for the German society. Then, the ethnicisation is cited as a justification for the lack of integration on the labour market. In the 'poverty immigration' discourse, it was shown that when poverty migrants were proved to be of economic benefit then this led conversely to a decrease in ethnicisation.

\section{Additional file}

Additional file 1: Program Code. (DOCX $19 \mathrm{~kb})$

\section{Acknowledgements}

The author would like to thank Cybelle Fox and Irene Bloemraad for organizing the Interdisciplinary Immigration Workshop at the UC Berkeley.

\section{Availability of data and materials}

The datasets used and/or analyzed during the current study are available from the corresponding author on reasonable request.

Authors' contributions

The research was carried out by Christian Ulbricht and the article was also written by Christian Ulbricht. The author read and approved the final manuscript.

Competing interests

The author declares that he has no competing interests.

\section{Publisher's Note}

Springer Nature remains neutral with regard to jurisdictional claims in published maps and institutional affiliations.

Received: 11 October 2018 Accepted: 23 April 2019

Published online: 30 July 2019

\section{References}

Adamson, F. B., Triadafilopoulos, T., \& Zolberg, A. R. (2011). The limits of the liberal state: Migration, identity and belonging in Europe. Journal of Ethnic and Migration Studies, 37(6), 843-859. https://doi.org/10.1080/1369183X.2011.576188.

Alba, R. (2005). Bright vs. blurred boundaries: Second-generation assimilation and exclusion in France, Germany, and the United States. Ethnic and Racial Studies, 28(1), 20-49. https://doi.org/10.1080/0141987042000280003.

Bail, C. A. (2008). The configuration of symbolic boundaries against immigrants in Europe. American Sociological Review, 73(1), 37-59. https://doi.org/10.1177/000312240807300103

Banting, K., \& Kymlicka, W. (2013). Is there really a retreat from multiculturalism policies? Comparative European Politics, 11, 577-598.

Barth, F. (1969). Ethnic groups and boundaries. Oslo: Universitetsforlaget. 
Bartolini, L., Gropas, R., \& Triandafyllidou, A. (2016). Drivers of highly skilled mobility from southern Europe: Escaping the crisis and emancipating oneself. Journal of Ethnic and Migration Studies, 43(4), 652-673. https://doi.org/10.1080/1369183X.2016. 1249048.

Bauer, T.K. (2013, February 21). Armutsmigration aus Osteuropa: "Wanderungsanreize für Sinti und Roma vermindern" [Poverty migration from Eastern Europe: "reducing migration incentives for Sinti and Roma"]. (interviewed by Martina Fietz for FOCUS online). Retrieved from https://www.focus.de/politik/deutschland/tid-29663/hartes-vorgehen-gegen-armutsmigrantenwanderungsanreize-fuer-sinti-und-romavermindern_aid_924482.html.

Becker, S., Dettmer, M., Flohr, M., Gezer, Ö., Kaiser, S., Nezik, A-K., .. Tietz, J. (2013, February 25). Der Deutsche Traum [The German Dream]. Der Spiegel, 9. Retrieved from https://www.spiegel.de/spiegel/print/d-91203388.html.

Benhabib, S. (1999). Citizens, residents, and aliens in a changing world: Political membership in the global era. Social Research, 66(3), 709-744. https://doi.org/10.2307/40971348?ref=no-x-route:e531a7d4c6170de1ca7f7d974ca4a4a9.

Bleich, E., Bloemraad, I., \& de Graauw, E. (2015). Migrants, minorities and the media: Information, representations and participation in the public sphere. Journal of Ethnic and Migration Studies, 41(6), 857-873. https://doi.org/10.1080/ 1369183X.2014.1002197.

Bonikowski, B. (2016). Nationalism in settled times. Annual Review of Sociology, 42(1), 427-449. https://doi.org/10.1146/ annurev-soc-081715-074412.

Bourdieu, P. (1989). Social space and symbolic power. Sociological Theory, 7(1), 14-25. https://doi.org/10.2307/202060.

Brubaker, R. (1992). Citizenship and nationhood in France and Germany. Cambridge: Harvard University Press.

Cerna, L. (2009). The varieties of high-skilled immigration policies: Coalitions and policy outputs in advanced industrial countries. Journal of European Public Policy, 16(1), 144-161. https://doi.org/10.1080/13501760802453148.

Cornelius, W. A., Martin, P. L., \& Hollifield, J. F. (1994). Introduction. In W. A. Cornelius, P. L. Martin, \& J. F. Hollifield (Eds.), Controlling immigration, (pp. 3-41). Stanford: Stanford University Press.

Deutscher Gewerkschafts Bund (DGB). (2014, January 21). Gemeinsame Erklärung von DGB und BDA zur Freizügigkeit [Joint Declaration by DGB and BDA on Free Movement] [Press release 009]. Retrieved from https://www.dgb.de/presse/++ co++961ab4fa-8288-11 e3-9597-52540023ef1a?search_text=Freiz\%C3\%BCgigkeit.

Diez, T., \& Squire, V. (2008). Traditions of citizenship and the securitisation of migration in Germany and Britain. Citizenship Studies, 12(6), 565-581. https://doi.org/10.1080/13621020802450643.

Dommer, M. (2010, November 24). "Blue Card". Hürdenlauf für Ausländer [Hurdles for foreigners]. Frankfurter Algemeiner (FAZ). Retrieved from https://www.faz.net/aktuell/beruf-chance/beruf/blue-card-huerdenlauf-fuer-auslaender-1 1065046.html.

Dribbusch, B. (2011, December 22). Einwanderung nach Deutschland: Gastarbeiter 2.0 [Immigration to Germany: Gastarbeiter 2.0]. TAZ. Retrieved from https://taz.de//5104735/.

Dribbusch, B. (2013, March 3). Noch ärmer als Hartz IV [Even poorer than Hartz IV]. TAZ. Retrieved from https:/taz.de/ $15072115 \%$.

Droht Deutschland eine Roma-Welle? [ls Germany threatened by a Roma wave?]. (2013, February 27). Bild. Retrieved from https:/www.bild.de/geld/wirtschaft/zuwanderung/droht-uns-eine-roma-welle-29296194.bild.html.

Eder, K., Rauer, V., \& Schmidtke, O. (2004). Die Einhegung des Anderen [The enclosure of the other]. Wiesbaden: VS Verlag für Sozialwissenschaften.

Elitz, E. (2010, July 31). Ausbilden statt kaufen [Training instead of buying]. Bild. Retrieved from https://www.bild.de/news/ standards/kommentar-von-ernst-elitz-13479260.bild.html.

Ellermann, A. (2015). Do policy legacies matter? Past and present guest worker recruitment in Germany. Journal of Ethnic and Migration Studies, 41(8), 1235-1253. https://doi.org/10.1080/1369183X.2014.984667.

Faist, T. (2014). On the transnational social question: How social inequalities are reproduced in Europe. Journal of European Social Policy, 24(3), 207-222. https://doi.org/10.1177/0958928714525814.

Faist, T. (2013). The mobility turn: A new paradigm for the social sciences? Ethnic and Racial Studies, 36(11), 1637-1646. https://doi.org/10.1080/01419870.2013.812229. Routledge.

Favell, A., \& Hansen, R. (2002). Markets against politics: Migration, EU enlargement and the idea of Europe. Journal of Ethnic and Migration Studies, 28(4), 581-601. https://doi.org/10.1080/1369183021000032218.

Frankfurter Algemeiner (FAZ). (2014, January 15). Unzulässige Panikmache [Inadmissible scare tactics].

Freeman, G. P. (1995). Modes of immigration politics in liberal democratic states. International Migration Review, 29(4), 881902. https://doi.org/10.2307/2547729.

Freemann, G. P. (1986). Migration and the political economy of the welfare state. The Annals of the American Academy of Political and Social Science, 485(1), 51-63. https://doi.org/10.1177/0002716286485001005.

Goodman, S. W. (2010). Integration requirements for integration's sake? Identifying, categorising and comparing civic integration policies. Journal of Ethnic and Migration Studies, 36(5), 753-772. https://doi.org/10.1080/13691831003764300.

Goodman, S. W. (2011). Controlling immigration through language and country knowledge requirements. West European Politics, 34(2), 235-255. https://doi.org/10.1080/01402382.2011.546569.

Goodman, S. W. (2015). Conceptualizing and measuring citizenship and integration policy: Past lessons and new approaches. Comparative Political Studies, 48(14), 1905-1941. https://doi.org/10.1177/0010414015592648.

Hampshire, J. (2013). The politics of immigration. Cambridge: Polity Press.

Hechter, M. (2004). From class to culture. American Journal of Sociology, 110(2), 400-445. https://doi.org/10.1086/421357.

Hellwig, T., \& Sinno, A. (2016). Different groups, different threats: Public attitudes towards immigrants. Journal of Ethnic and Migration Studies, 43(3), 339-358. https://doi.org/10.1080/1369183X.2016.1202749.

Hollifield, J. F. (1992). Immigrants, markets, and states. Cambridge: Harvard University Press.

Howard, M. M. (2006). Comparative citizenship: An agenda for cross-national research. Perspectives on Politics, 4(03), 443-455. https://doi.org/10.1017/S1537592706060294.

Hubrich, S. (2009). Tauziehen um Fremdarbeiter [Tug-of-war over Foreign Workers]. In R. Geißler, \& H. Pöttker (Eds.), Massenmedien und die Integration ethnischer Minderheiten in Deutschland The Mass Media and the Integration of Ethnic Minorities in Germany], (pp. 47-77). Bielefeld: Transcript.

Janoski, T. (2010). The ironies of citizenship. New York: Cambridge University Press.

Joppke, C. (2005). Exclusion in the liberal state the case of immigration and citizenship policy. European Journal of Social Theory, 8(1), 43-61. https://doi.org/10.1177/1368431005049327. 
Joppke, C. (2007). Beyond national models: Civic integration policies for immigrants in Western Europe. West European Politics, 30(1), 1-22. https://doi.org/10.1080/01402380601019613.

Jung, M., Wengeler, M., \& Böke, K. (2000). Ausländer und Migranten im Spiegel der Presse [Foreigners and Migrants through the Prism of the Press]. Wiesbaden: Westdeutscher Verlag.

Keller, R. (2012). Entering discourses: A new agenda for qualitative research and sociology of knowledge. Qualitative Sociology Review, 8(2), 46-75.

Kindleberger, C. P. (1967). Europe's postwar growth. Cambridge: Harvard University Press.

Koopmans, R., Michalowski, I., \& Waibel, S. (2012). Citizenship rights for immigrants: National political processes and crossnational convergence in Western Europe, 1980-2008. American Journal of Sociology, 117(4), 1202-1245. https://doi.org/10. 1086/662707.

Koopmans, R., Stathan, P., Giugni, M., \& Passy, F. (2005). Contested citizenship. Minneapolis: Uni. of Minnesota Press.

Lamont, M. (2012). Toward a comparative sociology of valuation and evaluation. Annual Review of Sociology, 38(1), $201-221$. https://doi.org/10.1146/annurev-soc-070308-120022.

Lamont, M., \& Molnár, V. (2002). The study of boundaries in the social sciences. Annual Review of Sociology, 28(1), 167-195. https://doi.org/10.1146/annurev.soc.28.110601.141107.

Laschet, A. (2009, October 13). "Was Sarrazin macht, verletzt Menschen" ["What Sarrazin does hurt People"]. Stern. Retrieved from https://www.stern.de/politik/deutschland/integrations-experte-laschet--was-sarrazin-macht--verletzt-menschen-3447424.html.

Link, A. (2012, November 3). Wegen Eurokrise- Italiener büffeln plötzlich wieder Deutsch [Because of euro crisis Italians are suddenly learning German again]. Bild. Retrieved from https://www.bild.de/politik/ausland/italien-krise/gastarbeiterwelledeutschland-26990248.bild.html.

O'Reilly, J., Eichhorst, W., Gábos, A., Hadjivassiliou, K., Lain, D., Leschke, J., . . Villa, P. (2015). Five characteristics of youth unemployment in Europe. SAGE Open, 5(1), 215824401557496. https://doi.org/10.1177/2158244015574962.

Orgad, L. (2015). The cultural defense of nations. Oxford: Oxford University Press.

Paul, R. (2013). Strategic contextualisation: Free movement, labour migration policies and the governance of foreign workers in Europe. Policy Studies, 34(2), 122-141. https://doi.org/10.1080/01442872.2013.767584.

Paul, R. (2016). Negotiating varieties of capitalism? Crisis and change in contemporary British and German labour migration policies. Journal of Ethnic and Migration Studies, 42(10), 1631-1650. https://doi.org/10.1080/1369183X.2016.1162357.

Sarrazin, T. (2009, October 5). Sarrazin und die Ruhestörung im Migrantenhain [Sarrazin and the disturbance in the migrant community] (interviewed by Ulrich Clauß for Die Welt). Retrieved from https://www.welt.de/politik/article4744082/ Sarrazin-und-die-Ruhestoerung-im-Migrantenhain.html.

Sarrazin, T. (2010a, August 29). Ich bin kein Rassist [I am not a Racist]. (Interviewed by Andrea Seibel; Hajo Schumacher; Joachim Fahrun for "Welt am Sontag")

Sarrazin, T. (2010b, August 23). Debatte: Was tun? [Debate: What to do?]. Der Spiegel, 34. Retrieved from https://www.spiegel. de/spiegel/print/d-73388944.html.

Schmidtke, O. (2008). Borders in public perception. In O. Schmidtke, \& S. Ozcurumez (Eds.), Of states, rights, and social closure, (pp. 91-112). New York: Palgrave MacMillan.

Schmidtke, O. (2012). Commodifying migration: Excluding migrants in Europe's emerging social model. The British Journal of Sociology, 63(1), 31-38. https://doi.org/10.1111/j.1468-4446.2011.01402.x.

Schmid, F. \& Ulrich, A. (2013, February 25). Pritsche ohne Kissen [Pallet without a Pillow]. Der Spiegel, 9. Retrieved from https:// www.spiegel.de/spiegel/print/d-91203389.html.

Schoepp, S. (2011, November 20). Spanier in Deutschland - Wir sind die neuen Gastarbeiter [Spaniards in Germany - We are the New Guest Workers]. SZ (Sueddeutsche Zeitung). Retrieved from https://www.sueddeutsche.de/karriere/ parlamentswahlen-in-spanien-wir-sind-die-neuen-gastarbeiter-1.1194231

Schönwälder, K. (2004). Why Germany's guestworkers were largely Europeans: The selective principles of post-war labour recruitment policy. Ethnic and Racial Studies, 27(2), 248-265. https://doi.org/10.1080/0141987042000177324.

Schütz, H.P., (2014, January 2). Seehofers Kreuther Kracher [Seehofers Kreuther Kracher]. Stern. Retrieved from https://www. stern.de/politik/deutschland/die-csu-und-die-armutszuwanderung-seehofers-kreuther-kracher-3134096.html.

Seibel, A. (2013, March 3). Einwanderung in den Sozialstaat verhindern [Prevent immigration into the welfare state]. Die Welt. Retrieved from https:/www.welt.de/debatte/kommentare/article1 14158133/Einwanderung-in-den-Sozialstaat-verhindern.html.

Soysal, Y. N. (2012). Citizenship, immigration, and the European social project: Rights and obligations of individuality. The British Journal of Sociology, 63(1), 1-21. https://doi.org/10.1111/j.1468-4446.2011.01404.x.

Spiegel Online (2014, January 15). CSU punktet mit Anti-Zuwanderungskurs [CSU scores with anti-immigration course]. [Blog post]. Retrieved from https://www.spiegel.de/forum/blog/umfrage-csu-punktet-mit-anti-zuwanderungskurs-thread-1 10806-1.html.

Strauss, A. L., \& Corbin, J. M. (1990). Basics of qualitative research. Grounded theory procedures and techniques. Thousand Oaks: Sage.

Stürmen Rumänen und Bulgaren unseren Job-Markt? [Are Romanians and Bulgarians storming our job market?] (2013, December 28). Bild. Retrieved from https://www.bild.de/geld/wirtschaft/freizuegigkeitsgesetz-eu/job-schranken-fallenstuermen-rumaenen-und-bulgaren-arbeitsmarkt-33999826.bild.html.

Triadafilopoulos, T. (2011). Illiberal means to liberal ends? Understanding recent immigrant integration policies in Europe. Journal of Ethnic and Migration Studies, 37(6), 861-880. https://doi.org/10.1080/1369183X.2011.576189.

Triadafilopoulos, T., \& Smith, C. D. (2013). Introduction. In T. Triadafilopoulos (Ed.) Wanted and Welcome? Policies for Highly Skilled Immigrants in Comparative Perspective, (pp. 1-14). New York: Springer New York. https://doi.org/10.1007/978-1-4614-0082-0.

Ulbricht, C. (2017). Ein- und Ausgrenzung von Migranten [Inclusion and exclusion of migrants]. Bielefeld: Transcript.

Van Houdt, F., \& Schinkel, W. (2013). Crime, citizenship and community: Neoliberal communitarian images of governmentality. The Sociological Review, 62(1), 47-67. https://doi.org/10.1111/1467-954X.12115.

Van Houdt, F., Suvarierol, S., \& Schinkel, W. (2011). Neoliberal communitarian citizenship: Current trends towards "earned citizenship" in the United Kingdom, France and the Netherlands. International Sociology, 26(3), 408-432. https://doi.org/ $10.1177 / 0268580910393041$.

Veto gegen Schengen-Beitritt Bulgariens und Rumäniens [Veto against the Schengen accession of Bulgaria and Romania]. (2013, March 3). Die Welt. Retrieved from https://www.welt.de/politik/deutschland/article114081854/Neto-gegenSchengen-Beitritt-Bulgariens-und-Rumaeniens.html. 
Wimmer, A. (2008). Elementary strategies of ethnic boundary making. Ethnic and Racial Studies, 31(6), 1025-1055. https://doi. org/10.1080/01419870801905612.

Wimmer, A. (2013). Ethnic boundary making. Oxford: Oxford University Press.

Yurdakul, G., \& Korteweg, A. C. (2013). Gender equality and immigrant integration: Honor killing and forced marriage debates in the Netherlands, Germany, and Britain. Women's Studies International Forum, 41, 204-214. https:/doi.org/10.1016/j.wsif.2013.07.011.

Zolberg, A. R. (1987). Wanted but not welcome. In W. Alonso (Ed.), Population in an interacting world, (pp. 36-73). Cambridge und London: Harvard University Press.

Zolberg, A. R., \& Woon, L. L. (1999). Why Islam is like Spanish: Cultural incorporation in Europe and the United States. Politics and Society, 27(1), 5-38. https://doi.org/10.1177/0032329299027001002.

Submit your manuscript to a SpringerOpen ${ }^{\circ}$ journal and benefit from:

- Convenient online submission

- Rigorous peer review

- Open access: articles freely available online

- High visibility within the field

- Retaining the copyright to your article

Submit your next manuscript at $\boldsymbol{\nabla}$ springeropen.com 